\title{
The Duty to Warn/Protect Doctrine and Its Application in Pennsylvania
}

Clarence Watson

Thomas Jefferson University

Follow this and additional works at: https://jdc.jefferson.edu/jeffjpsychiatry

Part of the Psychiatry Commons

Let us know how access to this document benefits you

\section{Recommended Citation}

Watson, Clarence (2005) "The Duty to Warn/Protect Doctrine and Its Application in Pennsylvania," Jefferson Journal of Psychiatry. Vol. 19 : Iss. 1 , Article 3.

DOI: https://doi.org/10.29046/JJP.019.1.002

Available at: https://jdc.jefferson.edu/jeffjpsychiatry/vol19/iss1/3

This Article is brought to you for free and open access by the Jefferson Digital Commons. The Jefferson Digital Commons is a service of Thomas Jefferson University's Center for Teaching and Learning (CTL). The Commons is a showcase for Jefferson books and journals, peer-reviewed scholarly publications, unique historical collections from the University archives, and teaching tools. The Jefferson Digital Commons allows researchers and interested readers anywhere in the world to learn about and keep up to date with Jefferson scholarship. This article has been accepted for inclusion in Jefferson Journal of Psychiatry by an authorized administrator of the Jefferson Digital Commons. For more information, please contact: JeffersonDigitalCommons@jefferson.edu. 


\title{
The Duty to Warn/Protect Doctrine and Its Application in Pennsylvania
}

\author{
Clarence Watson, JD, MD ${ }^{\mathrm{a}}$
}

\begin{abstract}
Despite the almost universal familiarity of mental health professionals with the Tarasoff case, many questions regarding its associated legal requirements often arise when evaluating potentially dangerous patients. The principles of the duty to warn/protect, while appearing nebulous at times, contain key concepts that the clinician must consider in the face of potential danger to third parties. This article reviews the landmark decision of the Tarasoff case and outlines its key concepts. In addition, given that state jurisdictions vary in treatment of Tarasoff-like cases, this article explores the Pennsylvania Supreme Court decision, Emerich v. Philadelphia Center for Human Development, Inc.
\end{abstract}

Key Words: duty to warn, duty to protect, Tarasoff, Emerich

\section{INTRODUCTION}

The eternal question of "what to do?" when a patient expresses a desire to harm another person, rings throughout the consciousness of psychiatrists and psychologists faced with this clinical challenge. Despite much attention that the legal issues involved with this topic have received over the years, many psychiatrists and psychologists only possess a vague concept of the duty to protect/warn principle, and are uncertain how it applies in their local practice area or how to approach each case.

This article will review the principle, explain the role of state law, and present important concepts to be considered when dealing with these cases. At the outset, we will cover the landmark case, Tarasoff v. Regents of University of California, which established the duty to protect. We will also review the principle as it applies in Pennsylvania.

\section{THE TARASOFF CASE}

In 1967, Prosenjit Poddar entered the University of California at Berkeley, as a graduate student. Approximately one year later, he met and befriended another student, Tatiana Tarasoff. They saw each other regularly throughout the fall of 1968. On New Year's Eve of that year, they shared a kiss. Poddar mistook the kiss as a sign of a romantic relationship. Tatiana informed Poddar that she was only interested in a platonic friendship.

Thereafter, Poddar became depressed and withdrawn. He expressed to a friend that he had thoughts of killing Tatiana. Throughout the spring of 1969 , he listened to secretly tape-recorded conversations with Tatiana in an effort to discover why she did not love him. In the summer of 1969, Tatiana traveled to Brazil. 
In Tatiana's absence, Poddar's mood began to improve. He followed a friend's advice and began seeing a psychologist, Dr. Lawrence Moore, at Cowell Memorial Hospital, an affiliate of the University of California. After several sessions, he informed Dr. Moore that he planned to kill an unnamed girl, who was readily identifiable as Tatiana. Almost immediately thereafter, Dr. Moore called campus police and sent a letter to the campus police chief notifying them that Poddar posed a danger to Tatiana and should be taken into custody for emergency psychiatric commitment.

Pursuant to Dr. Moore's request, campus police apprehended Poddar; however, they released him after he promised not to harm Tatiana. The director of the Department of Psychiatry, Dr. Harvey Powelson, learned of the failed commitment. Dr. Powelson directed Dr. Moore to request the return of his letter to the campus police. Dr. Powelson further instructed Dr. Moore to destroy the letter and any therapy notes regarding Poddar. In addition, Dr. Powelson told his staff to make no further efforts to commit Poddar. Thereafter, Poddar discontinued his treatment with Dr. Moore.

On October 27, 1969, Poddar killed Tatiana. Consequently, Poddar was tried for Tatiana's murder. He was convicted of second degree murder, but this conviction was overturned due to erroneous jury instructions. Given the complexity of the criminal trial and the length of time that passed since the initial conviction, the State of California did not retry Poddar. Instead, he was released on condition that he return to India and not reenter the United States.

Thereafter, Tatiana's parents filed a wrongful death lawsuit against the University of California and its employees, Dr. Moore, Dr. Powelson and the campus police. Initially, lower courts dismissed the case stating that no special relationship was present between the parties and therefore, no duty was owed to Tatiana or her parents. By way of background, common law states that generally there is no duty to control the conduct of a third party to prevent harm to another person, unless a special relationship is present (i). One example of a special relationship is that between a parent and child.

The Tarasoffs appealed the lower courts' decisions. As a result, the case was reviewed by the Supreme Court of California. In 1974, the Supreme Court of California sided with the Tarasoffs and established the duty to warn (ii). However, following criticisms by the American Psychiatric Association (APA) and similar groups, the Supreme Court of California reheard the case, vacated the 1974 decision, and in 1976 established the duty to protect. The 1976 decision stated that in the outpatient setting mental health professionals must take all reasonable steps necessary to protect foreseeable and identifiable third parties from patients who pose a serious threat to them (iii). Accordingly, the mental health professionals in the Tarasoff case were held liable for failing to protect Tatiana. The court found that the doctors failed to protect Tatiana by warning her or persons close to her who would warn her, or by securing commitment of Poddar to a psychiatric facility.

\section{POINTS LEARNED FROM TARASOFF}

There were multiple issues presented while the Supreme Court of California considered the Tarasoff case, however, the following points represent key concepts established by the court decision:

- Psychiatrists and psychologists have a 'special relationship' with their patients. As a result, mental health professionals are legally obligated to take reasonable steps to protect persons who have been identified by their patients as intended victims of future violence. It should be noted, that while the initial 1974 decision only established a duty to warn the intended victim, the 1976 decision does not restrict intervention to a warning. As a result, depending on the clinical setting, mental health professionals may protect intended victims by means other than warning, such as securing inpatient commitment or intensifying outpatient therapy.

- Public safety outweighs patient confidentiality. While patients are entitled to the confidentiality 
which underpins the doctor-patient relationship, the Tarasoff court explicitly stated that prevention of unnecessary acts of violence against the public outweighs patient confidentiality. In the words of the Tarasoff court, "The protective privilege ends where the public peril begins" (3). The court was clear, however, that unnecessary breaches of confidentiality would not be supported. Warnings given in the effort to carry out the duty must be provided in a manner that least offends a patient's right to confidentiality.

- Attempts to carry out the duty to protect must be done effectively. One must note that while the doctor in the above case contacted the campus police in an attempt to protect Tatiana Tarasoff, he took no further action to protect her after learning of the failed commitment of Poddar. Mental health professionals must monitor the clinical situation to be certain that the chosen intervention brought about its intended effect. In some cases, further action may be required, depending on the outcome of the initial intervention.

- Do not participate in unlawful destruction of patient documentation. Given the current medicolegal climate, it should go without saying that one should never destroy or cause to be destroyed documents related to patient care. Such actions would likely result in significant legal consequences.

\section{THINGS TO KEEP IN MIND}

It is inevitable during the course a psychiatrist's career that the question of "what to do?" will arise when a patient threatens violence. Regarding this issue, one must keep the following points in mind:

- The clinical assessment is crucial. Given the nature of psychotherapy, it is typical for patients to express many emotions, including anger towards others. When these expressions of anger involve threats of violence, a doctor must evaluate the seriousness of the intent. Clearly, the impulsive issuing of warnings to the public in the absence of thorough assessment of patients' threats would be improper. Likewise, minimizing such threats to mere expressions of anger without further assessment would be equally improper. A doctor must explore many factors in these situations, including any history of violence, formulation of a plan, and access to the threatened individual. Such assessment not only avoids the unnecessary breach of confidentiality, but also assists in determining reasonable clinical interventions.

- The law does not require accurate prediction of violent behavior. An argument against the dutyto-protect that has been presented claimed that mental health professionals are unable to accurately predict violent behavior. Courts have dismissed this argument by stating that there are no requirements for accurate prediction of violence. The law requires a reasonable standard of care of a mental health professional assessing a patient for potential dangerousness (iv). As courts point out, the lack of accurate predictability is something that all mental health professionals must face, and therefore, the reasonable standard of care used by these experts automatically accounts for inaccuracy (3).

- When considering possible interventions, include patient in the decision making process. Including the patient may preserve the trust previously established in the doctor-patient relationship. Such inclusion will promote continuation of the therapeutic alliance once the crisis has resolved. In addition, concerns regarding confidentiality may be addressed with the patient, who may agree to a warning, voluntary commitment, or both. Further, allowing the patient to discuss his intentions openly, along with the ramifications of those intentions, may serve as an initial step in the resolution of the crisis.

- Do not rely solely on police involvement. Although police are of great assistance in a majority of these cases, one must not assume that police officers have a full understanding of the issues at hand. 
A survey of Michigan and South Carolina police officers between 1998 and 1999 revealed that only $3 \%$ reported familiarity with the Tarasoff ruling and only $24 \%$ reported that their stations had a specific policy on warnings to third parties (v). This study suggests that police officers may have limited experience with mental health issues related to warning third parties. Therefore, doctors must not substitute the involvement of law enforcement for their own clinical judgment and intervention.

- The law regarding the duty to protect varies from state to state. The Tarasoff case represents California state law. Since state laws and policies vary, each state jurisdiction, when faced with similar facts, had to decide whether it would follow the Tarasoff decision. Many states have adopted some form of the duty established by the Tarasoff holding. Some states limit the duty, others expand the duty, while a few states ignore the duty altogether. Some state legislatures have established statutory law regulating the duty in order to minimize the confusion of doctors attempting to meet the legal standard. A recent study published in the Journal of the American Academy of Psychiatry and the Law calls into question the utility of these statutes given courts' varied interpretations or lack of inclusion of the statutory provisions (vi). Nonetheless, it is important for doctors to be familiar with the laws of the state in which they practice.

- Stay current. Equally as important as knowing the state law, one must be aware of changes in the law, since new cases may further clarify vague areas of existing law. For example, a recent California appellate court decision expanded the concept of patient-doctor communication as described by the state's duty to protect statute. In July 2004, the Superior Court of Los Angeles County ruled that "a communication from a family member to a therapist, made for the purpose of advancing a patient's therapy, is a patient communication. . . a therapist's duty to warn a victim arises if the information communicated leads the therapist to believe or predict that the patient poses a serious risk of grave bodily injury to another" (vii). In other words, communications from a family member regarding the potential dangerousness of a patient may now serve as basis for a duty to warn in California.

- Above and beyond the law, there is an ethical obligation to prevent harm when possible. While deciding on what action to take when a patient threatens violence may be a difficult and unsettling experience, it is a physician's ethical duty to prevent harm when possible. The prevention of harm not only protects the intended victim, but also serves to protect patients from the serious legal consequences of such violence. So, despite the presence or absence of legal requirements, the ethical obligation to prevent foreseeable injury to others persists.

\section{LAW IN PENNSYLVANIA}

Pennsylvania does not currently have statutory regulations governing the duty to protect/warn. However, this issue has been addressed by the Supreme Court of Pennsylvania in the 1998 decision of Emerich v. Philadelphia Center for Human Development, Inc. and Albert Einstein Medical Center (viii). The facts of the case are as follows:

In 1991, Teresa Hausler and Gad Joseph were romantically involved. At that time, they both received ongoing outpatient psychiatric care at the Philadelphia Center for Human Development (PCHD), which was operated by Albert Einstein Medical Center. Joseph had a long history of violent behavior, which included physical abuse directed towards Teresa. In the spring of 1991, Teresa ended the relationship and moved out of the apartment she shared with Joseph.

On the morning of June 27, 1991, Joseph called his counselor at PCHD and told him that he planned to kill Teresa. The counselor scheduled an emergency session with Joseph the same morning and recommended hospitalization. At 12:00 p.m., Joseph left the facility after he refused hospitalization and promised not to 
harm Teresa. At 12:15 p.m., Teresa called the counselor regarding Joseph's location, since she planned to return to the apartment to gather her belongings. The counselor warned her not to go to the apartment. Nevertheless, Teresa ignored the warning. She was killed by Joseph in the apartment at 12:30 p.m.

A civil lawsuit was initiated against PCHD for negligently failing to properly warn Teresa or others likely to warn her that Joseph presented a danger to her. The trial court found in favor of PCHD by ruling that the duty of mental health professionals to warn third parties had not been adopted in Pennsylvania and that, even if the duty existed, the counselor's conversation with Teresa discharged that duty. The Superior Court of Pennsylvania affirmed the decision.

On appeal to the Supreme Court of Pennsylvania, the court found that there is a duty owed to third parties by mental health professionals. Specifically, the court described the duty as follows:

". . . when the patient has communicated to the professional a specific and immediate threat of serious bodily injury against a specifically identified or readily identifiable third party and when the professional, determines, or should determine under the standards of the mental health profession, that his patient presents a serious danger of violence to the third party, then the professional bears a duty to exercise reasonable care to protect by warning the third party against such danger." (8)

Accordingly, given the counselor's attempted warning to Teresa during their conversation, no liability was established against the counselor or the facility.

While the court in Emerich referenced Tarasoff in support of its rationale, it should be noted that the duties created by the cases are not identical. Emerich established a duty to warn in Pennsylvania. It specifies the circumstances under which a third party must be warned. Further, the court intentionally excluded which actions discharge the duty to warn in Pennsylvania, other than directly warning victims. As stated by the court:

"Because of the facts before us ... we are not required to address the related issue of whether this duty to warn may be discharged by notifying relatives of the victim, other individuals close to the victim, or the police." (8)

In contrast, the court in Tarasoff established a duty to protect in California. The duty to protect is not limited to warning, and may be discharged by other reasonable means. Depending on the circumstances, a mental health professional may discharge the duty by hospitalizing the patient, initiating medications, intensifying psychotherapy or contacting the police.

The Emerich court acknowledges this distinction as follows:

"It is critical to note that the Tarasoff court found a duty to protect . . . a duty to warn is subsumed in this broader concept of a duty to protect. . . . we will only address the issue of protection in the context of a duty to warn the intended victim of danger . . . We leave for another day the related issue of whether some broader duty to protect should be recognized in this Commonwealth."

Consequently, while it appears that Emerich has provided an answer for whether a duty to third parties exists in Pennsylvania, it has left many more questions unanswered. Unfortunately, it seems that further clarification of these questions will require the presentation of a case with facts similar to those in Tarasoff.

\section{CONCLUSION}

The introduction of the duty to protect/warn has spawned much confusion for mental health professionals over the years. One reason for this has been the vague nature in which some state courts interpret the duty. 
While these professionals often seek guidance from the court system, they often find more questions than answers. For this reason, clinical judgment must be the fundamental tool by which the most appropriate intervention is achieved.

Appelbaum proposed a three-staged clinical approach for mental health professionals managing duty to protect cases (ix). The stages consist of assessment of the danger, selection of a course of action, and implementation of the course of action. Careful consideration of each stage is vital in yielding an outcome likely to prevent harm to third parties. Further, familiarity with the applicable state law may provide at least a hint of the minimal professional legal obligation. With these points in mind, mental health professionals should be better equipped to meet the ethical duty of averting harm, and in turn, should satisfy any imposed legal duty.

\section{REFERENCES}

1. Restatement (Second) of Torts, The American Law Institute (1965).

2. Tarasoff v. Regents of the University of California, et al, 529 P.2d 533 (Cal 1974).

3. Tarasoff v. Regents of the University of California, et al, 551 P.2d 334 (Cal 1976).

4. Rosner, R., Principles \& Practices of Forensic Psychiatry, Second Edition, Ch. 19; (2003 Arnold).

5. Huber MG, Balon R, et al: A survey of police officers' experience with Tarasoff warnings in two states. Psychiatr Serv 200; 51: 807-809.

6. Kachigian C, Felthous A: Court responses to Tarasoff statutes. J Am Acad Psychiatry Law 2004; 32:26373.

7. Ewing v. Goldstein, Cal. App.4th, [No. B163112. Second Dist., Div. Eight. Jul. 16, 2004.]

8. Emerich v. Philadelphia Center for Human Development, Inc., et al, 720 A.2d 1032 (PA 1998)

9. Appelbaum PS: Tarasoff and the clinician: problems in fulfilling the duty to protect. Am J Psychiatry 1985; 142: 425-429. 